\title{
Gas exchanges and growth of soybean cultivars submitted to water deficiency ${ }^{1}$
}

\author{
Jodean Alves da Silva², Pietros André Balbino dos Santos², \\ Luiz Gonsaga de Carvalho ${ }^{2}$, Ernandes Guedes Moura ${ }^{3}$, Fabrício Ribeiro Andrade ${ }^{4}$
}

\section{ABSTRACT}

A low availability of water in the soil may alter morphological traits and physiological processes in soybean, limiting its development, mainly at late sowings. This study aimed to evaluate the leaf gas exchanges and dry matter accumulation in soybean cultivars under low water availability at late sowing. An Oxisol with a very clayey texture was employed. A completely randomized design, in a $5 \times 3$ factorial scheme, with four replications, was used. The treatments were five water tensions $(10 \mathrm{kPa}, 15 \mathrm{kPa}, 25 \mathrm{kPa}, 40 \mathrm{kPa}$ and $60 \mathrm{kPa})$ combined with three soybean cultivars (BRS Favorita, BRSMG 820 and BRSMG 850). The response variables were measured at 55 days after the emergence. The values for stomatal conductance, transpiration, photosynthesis rate, intercellular $\mathrm{CO}_{2}$ concentration and instantaneous carboxylation efficiency were significantly reduced $(p<0.05)$ with the increase of the water tension in the soil. The gas exchanges in the soybean plants were also reduced with the increase of the water tension in the soil, being the most critical ones observed from $25 \mathrm{kPa}$. BRSMG 850 showed the best performance for production of root dry matter in this water tension in the soil.

KEYWORDS: Glycine max, instantaneous carboxylation efficiency, water tension in the soil.

\section{INTRODUCTION}

Brazil is the second largest producer of soybean [Glycine $\max$ (L.) Merrill], which is a crop of great importance in several areas, from the economic to the social one. Export rates of grains and derivatives exceeded 40 billion dollars in 2018 (Brasil 2019). Due to the high profitability of the sector, soybean has attracted interest to second crop cultivation.

\section{RESUMO}

Trocas gasosas e crescimento de cultivares de soja submetidas a déficit hídrico

A baixa disponibilidade de água no solo pode alterar atributos morfológicos e processos fisiológicos em soja, limitando o seu desenvolvimento, principalmente em semeaduras tardias. Avaliaramse trocas gasosas foliares e acúmulo de fitomassa seca em cultivares de soja sob condições de baixa disponibilidade hídrica, em semeadura tardia. Um Latossolo Vermelho de textura muito argilosa foi usado. O delineamento experimental foi inteiramente casualizado, em esquema fatorial $5 \times 3$, com quatro repetições. Os tratamentos foram cinco tensões de água ( $10 \mathrm{kPa}, 15 \mathrm{kPa}, 25 \mathrm{kPa}, 40 \mathrm{kPa}$ e $60 \mathrm{kPa})$ combinadas com três cultivares de soja (BRS Favorita, BRSMG 820 e BRSMG 850). As variáveis respostas foram mensuradas aos 55 dias após a emergência. Os valores de condutância estomática, transpiração, taxa de fotossíntese, concentração intercelular de $\mathrm{CO}_{2}$ e eficiência de carboxilação instantânea foram reduzidos significativamente $(\mathrm{p}<0,05)$ com o aumento da tensão de água no solo. As trocas gasosas nas plantas de soja também foram reduzidas com o aumento da tensão da água no solo, e as mais críticas foram observadas a partir de $25 \mathrm{kPa}$. BRSMG 850 apresentou o melhor desempenho para produção de matéria seca de raízes nesta tensão de água no solo.

PALAVRAS-CHAVE: Glycine max, eficiência instantânea de carboxilação, tensão de água no solo.

The development of soybean plants is influenced by several environmental conditions, such as temperature, rainfall, relative humidity, soil moisture and photoperiod (Embrapa 2011, Farias et al. 2007). Considering the variations of these conditions during the year and soybean responses, no other single factor influences the soybean development and yield as much as the sowing period.

Suboptimal temperatures and water deficits are the main abiotic conditions that restrict the

1. Received: June 03, 2019. Accepted: Nov. 08, 2019. Published: Apr. 17, 2020. DOI: 10.1590/1983-40632020v5058854.

2. Universidade Federal de Lavras, Lavras, MG, Brasil. E-mail/ORCID: jodean2013@gmail.com/0000-0003-4860-1190, pietros.balbino@gmail.com/0000-0002-4672-8369, lgonsaga@ufla.br/0000-0001-6753-4419.

3. Instituto Federal de Educação, Ciência e Tecnologia do Maranhão, São João dos Patos, MA, Brasil. E-mail/ORCID: ernandesfederal@hotmail.com/0000-0003-2057-5736.

4. Instituto Federal de Educação, Ciência e Tecnologia de Mato Grosso, Juína, MT, Brasil. E-mail/ORCID: fabricio.andrade@jna.ifmt.edu.br/0000-0003-1865-6502. 
plant growth, and these stresses naturally occur at the same period (Jumrani \& Bhatia 2017). The combination of low water availability in the soil, duration of light hours per day (photoperiod) and temperature (Freitas et al. 2010) may strongly affect physiological processes (Manavalan et al. 2009) and plant morphological parameters in late sowing.

Water deficits in the reproductive phase of the soybean crop leads to a reduction in photosynthesis, as well as leaf area and biomass production. Soybean requires at least $450 \mathrm{~mm}$ of water per cycle and $7.5 \mathrm{~mm}$ daily during the flowering phase (Farias et al. 2007). Although plants can recover from stress to a certain extent, there are severe yield losses (Bhatia \& Jumrani 2016, Jumrani \& Bhatia 2017, Jumrani et al. 2017). This condition is very common in central Brazil, where there are long periods of water deficit in the soil due to interruptions in rainfall during the rainy season (Assad \& Sano 1998).

Genotype-dependent characteristics may minimize the effects of water deficit on soybean cultivars with determinate and indeterminate growth habits, maintaining high relative contents of water in leaves (Fioreze et al. 2011, Silva et al. 2018). However, in the presence of water deficits, plants promote a stomatal closure, interrupting the $\mathrm{CO}_{2}$ and water flow through transpiration and limiting the $\mathrm{CO}_{2}$ assimilation and availability in the leaf mesophyll, which maintains the water balance (Kerbauy 2008, Silva et al. 2015).

The reduction of the assimilation rate of $\mathrm{CO}_{2}$ in leaves could induce the remobilization of stored carbohydrates to tissues with higher demand, thus affecting the development and yield of the crop. In this perspective, studies that seek to understand the physiological responses of soybean as a function of water tension in the soil in late sowing, that elucidate relationships of physical and hydrous properties with below critical photoperiods, have been of great importance, since there are few studies addressing leaf gas exchange due to water deficit and below critical photoperiod. Therefore, this study aimed to evaluate the leaf gas exchange and dry matter accumulation in soybean cultivars submitted to water deficiency and late sowing.

\section{MATERIAL AND METHODS}

The experiment was conducted under greenhouse conditions, at the Universidade Federal de Lavras, Minas Gerais state, Brazil (21 ${ }^{\circ} 14^{\prime} 10^{\prime}$ 'S, $45^{\circ} 00$ ' $10^{\prime}$ 'W and altitude of $918.841 \mathrm{~m}$ ), from March to April 2016. The data for maximum and minimum temperatures and air relative humidity were obtained from an automatic station located inside the greenhouse. These data and the critical and estimated photoperiods are shown in Figure 1.

Pots were filled with a very clayey Oxisol ("Latossolo Vermelho distroférrico", according to the Brazilian classification system), which was collected from the $0-0.20 \mathrm{~m}$ layer in cattle pasture, dried in the air and ground to pass through a 2-mm sieve. Soil samples were analyzed for physical and chemical attributes, as it follows: $150 \mathrm{~g} \mathrm{~kg}^{-1}$ of sand; $180 \mathrm{~g} \mathrm{~kg}^{-1}$ of silt; $670 \mathrm{~g} \mathrm{~kg}^{-1}$ of clay; $\mathrm{pH}\left(\mathrm{H}_{2} \mathrm{O}\right)=6.3 ; \mathrm{H}+\mathrm{Al}^{3+}=$ $3.27 \mathrm{cmol}_{\mathrm{c}} \mathrm{dm}^{-3} ; \mathrm{Al}^{3+}=0.0 \mathrm{cmol}_{\mathrm{c}} \mathrm{dm}^{-3} ; \mathrm{P}($ Mehlich-1 $)=$ $1.13 \mathrm{mg} \mathrm{dm}^{-3} ; \mathrm{K}=58.0 \mathrm{mg} \mathrm{dm}^{-3} ; \mathrm{Ca}^{2+}=2.8 \mathrm{cmol}_{\mathrm{c}} \mathrm{dm}^{-3}$; $\mathrm{Mg}=0.6 \mathrm{cmol}_{\mathrm{c}} \mathrm{dm}^{-3} ; \mathrm{CEC}=6.82 \mathrm{cmol}_{\mathrm{c}} \mathrm{dm}^{-3} ;(\mathrm{V} \%)=$ $52.0 \mathrm{~g} \mathrm{dm}^{-3}$; organic matter $=25.5 \mathrm{~g} \mathrm{dm}^{-3}$.

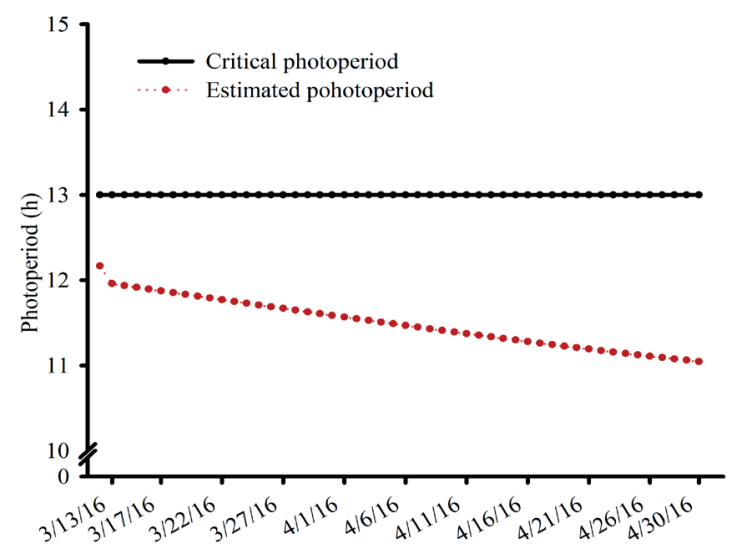

Figure 1. Maximum $\left(\mathrm{T}_{\max }\right)$ and minimum $\left(\mathrm{T}_{\min }\right)$ air temperatures, air relative humidity $\left(\mathrm{RH}_{\text {air }}\right)$ and critical and estimated photoperiods during the conduction of the experiment. Data obtained from an Agrosystem ${ }^{\circledR}$ Vantage Pro2 meteorological station. 
Based on the chemical analysis, soil liming was carried out to increase the saturation by $60 \%$, using calcium carbonate $\left(\mathrm{CaCO}_{3}\right)$ and magnesium carbonate $\left(\mathrm{MgCO}_{3}\right.$; pure analytic - PA) at a ratio of $4: 1$. The soil was incubated for 30 days with moisture close to $60 \%$ of the total pore volume. Fertilization was applied according to Malavolta (1980): $80 \mathrm{mg}$ of nitrogen $(\mathrm{N}), 300 \mathrm{mg}$ of phosphorus $(\mathrm{P}), 200 \mathrm{mg}$ of potassium (K) and $50 \mathrm{mg}$ of sulfur $(\mathrm{S})$ per $\mathrm{dm}^{3}$ of soil, which were supplied as monobasic ammonium phosphate $\left(\mathrm{NH}_{4} \mathrm{H}_{2} \mathrm{PO}_{4}\right)$, monopotassium phosphate $\left(\mathrm{KH}_{2} \mathrm{PO}_{4}\right)$ and magnesium sulfate $\left(\mathrm{MgSO}_{4} \cdot 7 \mathrm{H}_{2} \mathrm{O}\right)$, respectively. Micronutrient fertilization consisted of $0.5 \mathrm{mg}$ of $\mathrm{B}, 1.5 \mathrm{mg}$ of $\mathrm{Cu}, 0.1 \mathrm{mg}$ of $\mathrm{Mo}$ and $5.0 \mathrm{mg}$ of $\mathrm{Zn}$ per $\mathrm{dm}^{3}$ of soil, which were provided as boric acid $\left(\mathrm{H}_{3} \mathrm{BO}_{3}\right)$, copper sulfate $\left(\mathrm{CuSO}_{4} \cdot 5 \mathrm{H}_{2} \mathrm{O}\right)$, ammonium molybdate $\left[\left(\mathrm{NH}_{4}\right)_{6} \mathrm{Mo}_{7} \mathrm{O}_{24} \cdot 4 \mathrm{H}_{2} \mathrm{O}\right]$ and zinc sulfate $\left(\mathrm{ZnSO}_{4} \cdot 7 \mathrm{H}_{2} \mathrm{O}\right)$, respectively.

Five soybean seeds were sown per pot and, at ten days after the seedling emergence, the seedlings were thinned to three plants per pot. During the growing period, fertilization with $100 \mathrm{mg}$ of K per $\mathrm{dm}^{3}$ of soil (divided into two applications) was carried out using potassium chloride $(\mathrm{KCl})$ at 25 and 40 days after sowing.

The experiment followed a completely randomized design, arranged in a $5 \times 3$ factorial scheme, with four replications. Thus, the treatments were five water tensions in the soil $(10 \mathrm{kPa}, 15 \mathrm{kPa}$, $25 \mathrm{kPa}, 40 \mathrm{kPa}$ and $60 \mathrm{kPa}$ ) combined with three soybean $\mathrm{RR}^{\circledR}$ (Roundup Ready) cultivars (BRS Favorita, BRSMG 820 and BRSMG 850). These cultivars belong to the maturity groups 7.9, 8.2 and 8.2 , respectively, and are recommended for the region due to their high yields. Each pot had a volume of $20 \mathrm{dm}^{3}(0.30 \mathrm{~m}$ in height and $0.292 \mathrm{~m}$ in diameter).

Prior to sowing, the soybean seeds were treated with pyraclostrobin + methyl thiophanate + fipronil, at a dose of $2 \mathrm{~mL}$ (c.p. - commercial product) $\mathrm{kg}^{-1}$ of seeds and inoculated with Bradyrhizobium japonicum at the dose of $4 \mathrm{~mL}$ c.p. $\mathrm{kg}^{-1}$ of seeds.

In order to determine the water retention curve in the soil, soil samples were saturated and then subjected to tensions of $2 \mathrm{kPa}, 4 \mathrm{kPa}, 6 \mathrm{kPa}$ and $10 \mathrm{kPa}$ in suction units (Büchner funnels), and to $33 \mathrm{kPa}, 100 \mathrm{kPa}, 500 \mathrm{kPa}$ and 1,500 kPa in Richards' extraction chambers. The retention curve in the soil was obtained from the data of moisture and soil matric potentials using the SigmaPlot software (Systat 2013). The curve was fitted to the model proposed by van Genuchten (1980), with the restriction of Mualem (1976), given by $m=1-1 / n$. This model describes the behavior of the soil volumetric moisture $\left(\theta\right.$, in $\left.\mathrm{m}^{3} \mathrm{~m}^{-3}\right)$ as a function of the soil matric potential $(\mathrm{h}$, in $\mathrm{kPa})$, related to the soil water potential as: $\theta=\theta_{\mathrm{r}}+\left(\theta_{\mathrm{s}}-\theta_{\mathrm{r}}\right) /$ $\left[1+(\alpha \times \mathrm{h})^{\mathrm{n}}\right]^{(1+1 / \mathrm{n})}$. The generated parameters were: $\theta_{\mathrm{r}}=0.239 ; \theta_{\mathrm{s}}=0.534 ; \alpha=0.908 ;$ and $\mathrm{n}=1.478$, which resulted in a model with a high determination coefficient $\left(\mathrm{R}^{2}=0.99 * *\right)$.

The treatments started at 25 days after the plant emergence. Irrigation management considered the matric potentials, pre-established soil-water indicators to return to the soil moisture at $70 \%$ of the field capacity $(\theta c c)$, and soil moisture before applying the ideal treatments for soybean cultivation (Embrapa 2013). Two soil moisture sensors (Watermark ${ }^{\circledR}$ ) were installed for each treatment at a depth of $0.20 \mathrm{~m}$. The field capacity was considered in the tension of $6 \mathrm{kPa}$, corresponding to the volumetric moisture of $0.367 \mathrm{~m}^{3} \mathrm{~m}^{-3}$ and permanent wilting point $(\theta \mathrm{pmp})$ of $0.248 \mathrm{~m}^{3} \mathrm{~m}^{-3}$.

The irrigation levels consisted of water replacement when the water tension in the soil reached $10 \mathrm{kPa}, 15 \mathrm{kPa}, 25 \mathrm{kPa}, 40 \mathrm{kPa}$ and $60 \mathrm{kPa}$ at $0.20 \mathrm{~m}$ of depth.

Water was added manually in the pot in an amount ( $f$ ) calculated according to the equation described by Rios et al. (2014): $\mathrm{f}=($ AWC/TWA $) \times$ 100 , with $\mathrm{AWC}=[(\theta \mathrm{cc}-\theta \mathrm{a})] \times \mathrm{Z}$ and TWC $=[(\theta \mathrm{cc}-$ $\theta$ pmp) $] \times \mathrm{Z}$, where: AWC is the actual water capacity in the soil (decimal); TWC the total water capacity in the soil (decimal); $\theta$ cc the soil moisture at field capacity; $\theta$ a the soil moisture at the tension defined for each water level ( $\left.\mathrm{m} \mathrm{m}^{-3}\right)$; $\theta \mathrm{pmp}$ the soil moisture at the permanent wilting point $\left(\mathrm{m} \mathrm{m}^{-3}\right)$; and $\mathrm{Z}$ the effective depth of the root system $(\mathrm{mm})$, corresponding to the depth of the vessels.

Light was added to correct the photoperiod, which was determined by the difference between the photoperiod of the soybean-planting season in the Minas Gerais state (until November 15) and during the conduction of the experiment. Fluorescent lamps (40 watts) were used with characteristics that approximated to the sunlight, spaced at $4.0 \mathrm{~m}$ at a height of $2.5 \mathrm{~m}$. The control of lighting hours was done automatically, using an analog timer.

At 55 days after the emergence and 30 days after the replacement of water in the soil at each tension, leaf gas exchange evaluations were performed using a portable infrared gas analyzer (IRGA - 6400 XT, 
LiCOR, Nebraska, USA). The net assimilation rate of $\mathrm{CO}_{2}\left(A ; \mu \mathrm{mol} \mathrm{CO} \mathrm{m}^{-2} \mathrm{~s}^{-1}\right)$, stomatal conductance $\left(g s ; \mathrm{mol} \mathrm{H}_{2} \mathrm{O} \mathrm{m}^{-2} \mathrm{~s}^{-1}\right)$, transpiration rate $(E ; \mathrm{mmol}$ $\left.\mathrm{H}_{2} \mathrm{O} \mathrm{m}^{-2} \mathrm{~s}^{-1}\right)$ and internal $\mathrm{CO}_{2}$ concentration $(i C$; $\mu \mathrm{mol} \mathrm{CO} \mathrm{Col} \mathrm{air}^{-1}$ ) were obtained. Based on these data, other physiological variables were calculated, such as: i) instantaneous carboxylation efficiency $(i C E)=A / i C\left(\mathrm{~mol} \mathrm{air}{ }^{-1}\right)$; ii) water-use efficiency $(W U E)=A / E\left[\mu \mathrm{mol} \mathrm{CO} \mathrm{CO}_{2}\left(\mathrm{mmol} \mathrm{H}_{2} \mathrm{O}\right)^{-1}\right]$; and instantaneous water-use efficiency $(i W U E)=A / C i$ $\left[\mu \mathrm{mol} \mathrm{CO} 2\left(\mu \mathrm{mol} \mathrm{CO} \text { mol air }^{-1}\right)^{-1}\right]$. Evaluations were carried out on sunny days, between 9:00 a.m. and 11:00 a.m., from the last fully developed leaf. The photosynthetically active radiation was standardized for artificial saturating light of $1,000 \mathrm{mmol} \mathrm{m}^{-2} \mathrm{~s}^{-1}$ and ambient $\mathrm{CO}_{2}$ concentration. The average relative humidity was $69 \%$, and the average ambient temperature was $22{ }^{\circ} \mathrm{C}$.

At the end of the study, the shoot parts of the plants were sectioned at the base of the stem and the leaf area was determined using a leaf area meter (LI3100 Meter Area/LI-COR Inc. Lincoln, NE, USA). The leaf area index (LAI) was measured according to Almeida et al. (2014), using the formula: LAI = leaf area $\left(\mathrm{m}^{2}\right) /$ surface covered by the plant $\left(\mathrm{m}^{2}\right)$. The roots were washed to calculate the root volume, which was determined by the volume of water displaced in a beaker. The shoot and root dry matter were determined after drying the plants in a forced circulation oven at $65^{\circ} \mathrm{C}$, for $72 \mathrm{~h}$, when the mass is constant, followed by weighing.

For the data analyses, firstly, normality was analysed using the Anderson-Darling test and homoscedasticity was verified using the Levene test, both at $5 \%$ of significance $(\alpha=0.05)$. After that, the data for each variable were submitted to analysis of variance, in which the means for the qualitative factor levels were compared by the Scott-Knott test $(\alpha=0.05)$. The quantitative factors were submitted to regression analysis using the $\mathrm{R}$ statistical software, version 3.2.3 (RDCT 2016).

\section{RESULTS AND DISCUSSION}

The variables stomatal conductance $(g s)$, transpiration $(E)$, internal $\mathrm{CO}_{2}$ concentration $(i C)$, photosynthesis rate $(A)$, water-use efficiency $(W U E)$, instantaneous water-use efficiency $(i W U E)$ and instantaneous carboxylation efficiency $(i C E)$ significantly $(\mathrm{p}<0.05)$ decreased with the reduction of water availability in the soil (Figure 2). A lower gs value $\left(0.32 \mathrm{~mol} \mathrm{H}_{2} \mathrm{O} \mathrm{m}^{-2} \mathrm{~s}^{-1}\right)$ was observed at tensions between $40 \mathrm{kPa}$ and $60 \mathrm{kPa}$, for the BRSMG 850 cultivar. These results partially corroborate those by Machado Júnior et al. (2017), who obtained $g s$ values higher than $0.25 \mathrm{~mol} \mathrm{H}_{2} \mathrm{O} \mathrm{m}^{-2} \mathrm{~s}^{-1}$ in soybean cultivars grown without water stress, with a two-day irrigation shift. However, a turgescence loss was verified with the reduction of the $g s$ rate in these potentials, due to stomatal closure. It was influenced by the water potential in the foliar tissues, providing less stomatal opening and resulting in the reduction of $E$ to a value of $4.0 \mathrm{mmol} \mathrm{H}_{2} \mathrm{O} \mathrm{m}^{-2} \mathrm{~s}^{-1}$ (Figure 2). This result partially corroborates Chavarria et al. (2015), who verified reductions of $E(90 \%)$ in soybean under two to eleven days without applying water to the soil, with water tensions of $0.4 \mathrm{kPa}$ to $16.4 \mathrm{kPa}$, respectively.

The lower partitioning of water from the foliar tissues to the atmosphere through transpiration by the reduction of $g s$ is a strategy of the plant to adapt to the temporal variability of water in the soil by water replacement. This compromises the physiological process of the soybean in the water tension of $60 \mathrm{kPa}$, with reduced values, when compared with the smaller water tensions of $10 \mathrm{kPa}, 15 \mathrm{kPa}, 25 \mathrm{kPa}$ and $40 \mathrm{kPa}$. Gas exchanges are controlled by meteorological elements (Taiz \& Zeiger 2017), decreasing the flow of water vapor into the atmosphere, since it is directly related to transpiration (Blum 2009, Gonçalves et al. 2010).

The lower water availability in the soil promoted stomatal closure, reducing the normal $\mathrm{CO}_{2}$ flow towards the carboxylation site. This resulted in an internal $\mathrm{CO}_{2}$ concentration of $315 \mu \mathrm{mol} \mathrm{CO} \mathrm{mol} \mathrm{air}^{-1}$ at $60 \mathrm{kPa}$ (Figure 2). The reduction of the atmospheric $\mathrm{CO}_{2}$ supply caused by stomatal closure due to the low availability of water in the soil (Hopkins \& Hüner 2009, Manavalan et al. 2009) led to a reduction in the photosynthesis rate $(A)$, with values up to $7 \mu \mathrm{mol}$ $\mathrm{CO}_{2} \mathrm{~m}^{-2} \mathrm{~s}^{-1}$. Chavarria et al. (2015) verified similar results when submitting the BMX Apolo RR soybean cultivar to a water tension in the soil of $26 \mathrm{kPa}$, at six days without applying water to the soil. There was a reduction in the photosynthetic rates to $6.7 \mu \mathrm{mol}$ $\mathrm{CO}_{2} \mathrm{~m}^{-2} \mathrm{~s}^{-1}$, for a medium-textured soil. Likewise, Machado Júnior et al. (2017) verified a reduction in $A$ when submitting soybean plants to a moderate water stress (50\% of water volume applied to the control soil at field capacity), which was similar to the results found in the present study. 

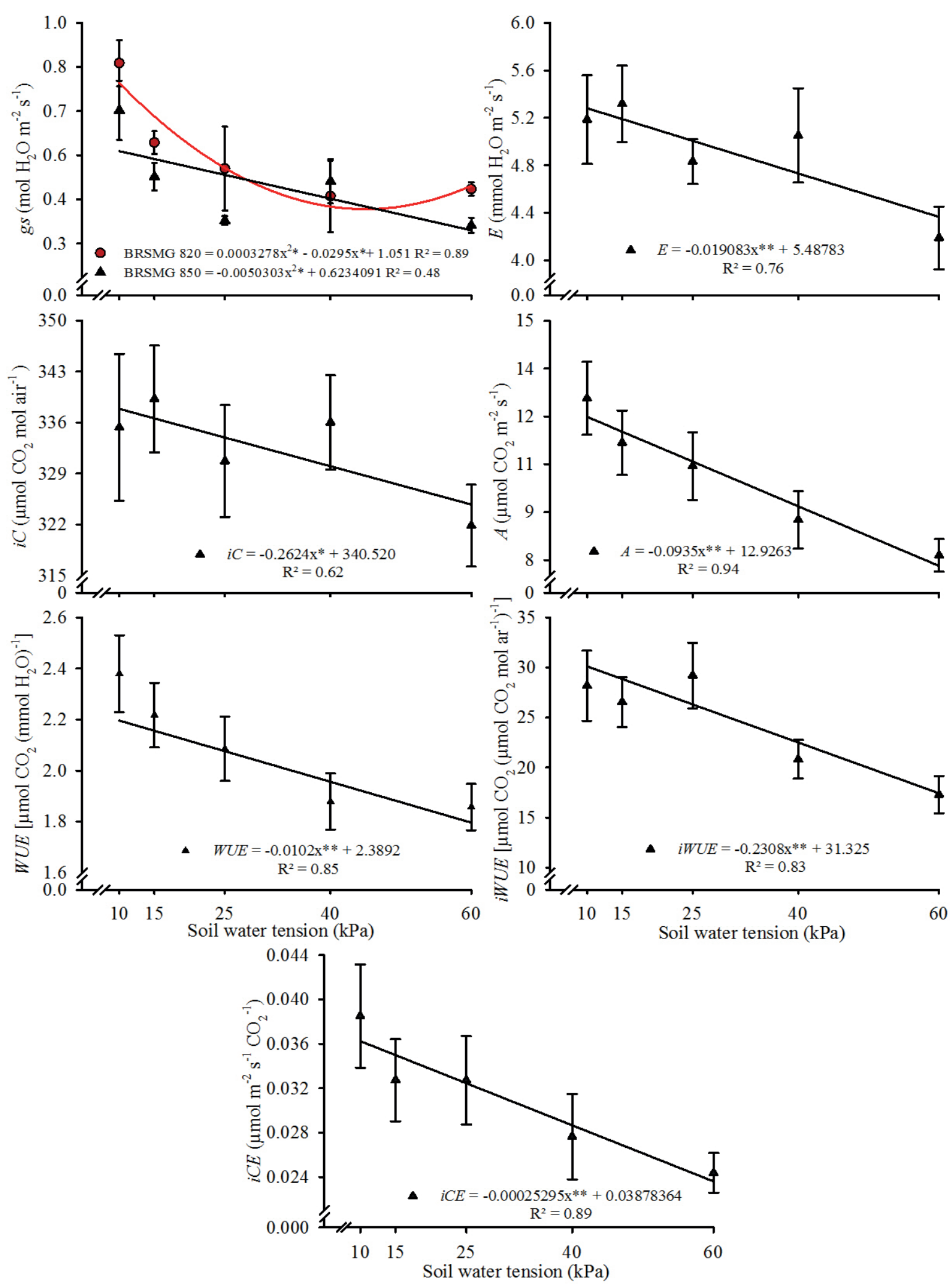

** and $*$ significant at $1 \%$ and $5 \%$ of probability, respectively, by the t-test

Figure 2. Responses for stomatal conductance $(g s)$, transpiration $(E)$, intercellular $\mathrm{CO}_{2}$ concentration $(i C)$, net photosynthesis rate $(A)$, water-use efficiency $(W U E)$, intrinsic water-use efficiency $(i W U E)$ and instantaneous carboxylation efficiency $(i C E)$, as a function of water tension $(\mathrm{kPa})$ in the soil, for different soybean cultivars. The interaction between the factors was only significant $(\mathrm{p}<0.05)$ for the variable $g s$. Vertical bars on each observed mean are the respective standard errors. 
The reduction of liquid photosynthesis in soybean cultivation is related to water stress, limiting the assimilation of $\mathrm{CO}_{2}$ (Hong-Bo et al. 2008, Kerbauy 2008, Bosco et al. 2009, Silva et al. 2015). This results in less ATP, NADPH and substrate for the activity of the enzyme ribulose bisphosphate carboxylase/oxygenase - Rubisco (Silva et al. 2015), reducing the growth of roots and shoots, as verified in this study (Figure 3). In such conditions, the plant uses $\mathrm{CO}_{2}$ from respiration depending on the solar radiation, which determines the carbon balance to maintain a minimum level of photosynthetic rate (Taiz \& Zeiger 2017). This may have been aggravated by the early soybean flowering, even with the photoperiod below the compensated critical value (Figure 1) and the prolongation of the water deficit.

The variables related to physiological efficiency, such as $W U E, i W U E$ and $i C E$, followed similar behaviors when compared to $g s, i C$ and $E$, with reductions of $31 \%, 80 \%$ and $58 \%$, respectively, when the water tension in the soil incremented from $10 \mathrm{kPa}$ to $60 \mathrm{kPa}$ (Figure 2). When comparing the results of the present study with those obtained in soybean plants grown at the recommended sowing season, high $i C$ values were associated with increased $g s$. Furthermore, there was a decrease in $i C E$, which might be associated with the low temperature in latesown soybean (Figure 1).

The $i C E$ is a trait associated with stomatal conductance (gs) (Manavalan et al. 2009) and transpiration efficiency. Given that these traits are related to $i W U E$ and $W U E$, where the lowest values maintained a minimum water equilibrium, there was a limitation of $\mathrm{CO}_{2}$ assimilation in the soil with low water availability. This was significantly reflected in the reduction of $i C E$ (Figure 2) and, according to Silva et al. (2015), a low concentration of intercellular $\mathrm{CO}_{2}$ restricting its flux in the cells of the mesophyll. Likewise, temperatures below $13{ }^{\circ} \mathrm{C}$ (Figure 1), according to Taiz \& Zeiger (2017), may alter the enzymatic activity, reducing the cellular metabolism in order to reduce the liquid photosynthesis rate.

Regardless of the evaluated cultivar, the leaf area index (LAI), shoot and root dry matter, and root volume decreased with the increase in the water tension in the soil (Figure 3). The lower water
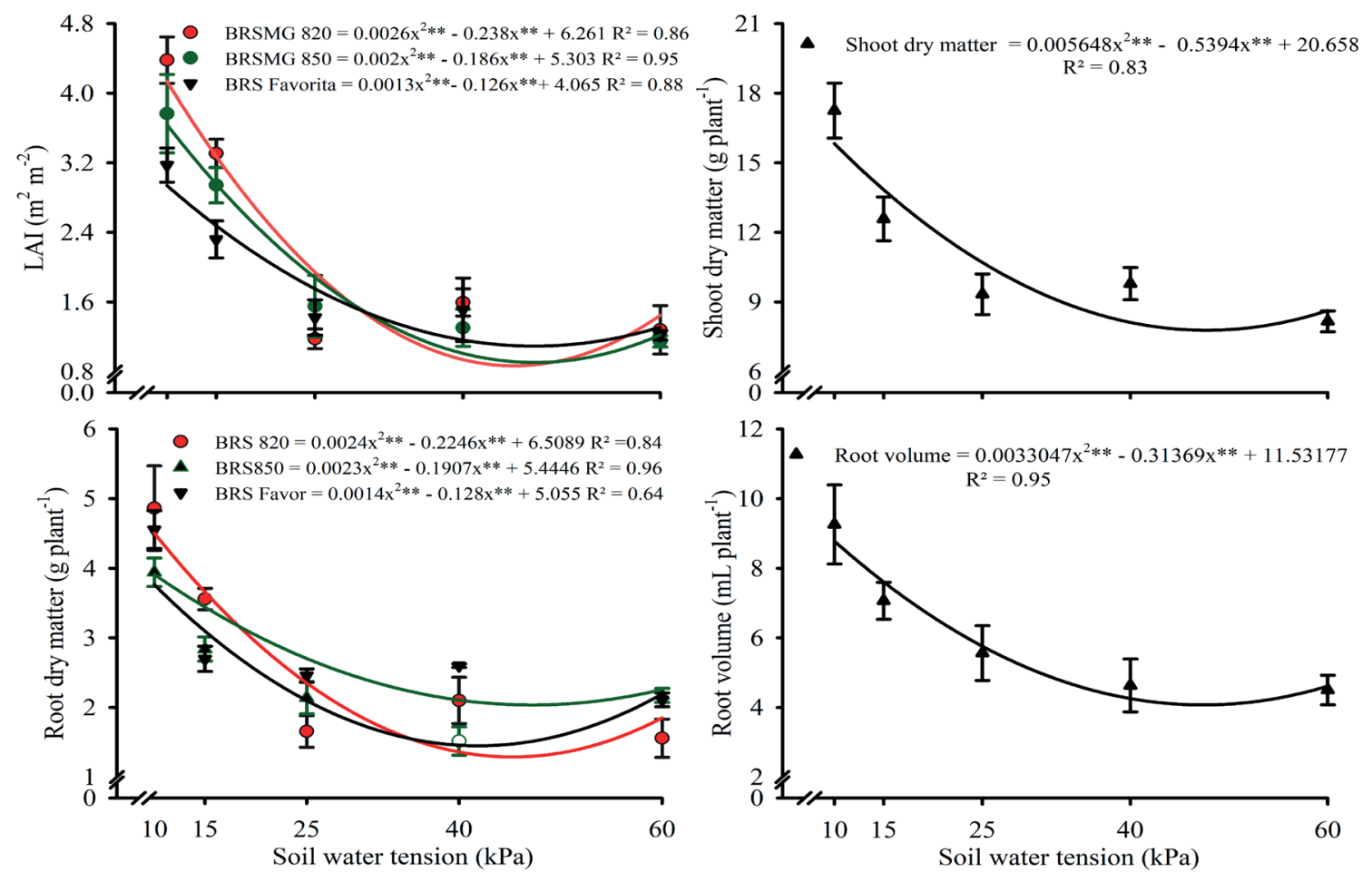

** and $*$ significant at $1 \%$ and $5 \%$ of probability, respectively, by the t-test

Figure 3. Response of the leaf area index (LAI), shoot and root dry matter, and root volume, as a function of water tension (kPa) in the soil, for different soybean cultivars. The interaction between the factors was only significant $(\mathrm{p}<0.05)$ for the variables LAI and root dry matter. Vertical bars on each observed mean are the respective standard errors. 
availability in the soil at $60 \mathrm{kPa}$ reduced the LAI, with lower emissions and leaf expansion. This was directly reflected in the shoot dry matter, since, in this same potential, the reduction was $111 \%$, when compared with the tension of $10 \mathrm{kPa}$. Chavarria et al. (2015) verified a $24 \%$ reduction of leaf area for the BMX Apolo RR soybean cultivar, in the interval from two to eleven days, with water restriction at tensions between $0.4 \mathrm{kPa}$ and $16.4 \mathrm{kPa}$, for a medium-textured soil. However, it was not significantly influenced by the variation in the water availability, as it did not reach the critical level for water deficit.

This smaller water availability for a higher water tension in the soil reduced the leaf growth, what reflected in a lower shoot dry matter and, consequently, a reduction of $105 \%$ for root dry matter and root volume (Figure 3). Benjamin \& Nielsen (2006) and Machado Júnior et al. (2017) did not detect significant changes in the root distribution of soybean under low water availability.

The reduction on morphological traits in soybean is related to the fact that the roots send chemical signals to the plant shoot, thus reducing the transpiration rate (Rahnama et al. 2011, Tardieu 2013), due to the lower flow of water from the soil to the xylem and from the leaves to the atmosphere (Santos et al. 2012). This also reduces the stomatal opening, what causes a lower absorption of $\mathrm{CO}_{2}$ and less mobilization of photoassimilates to the roots, thus reducing the root dry matter and root volume.

The increase of the water tension in the soil also reduced the photosynthetic traits $(A, g s$ and $E$ ), since water is essential to provide electrons to chlorophyll, for the conversion of light energy into chemical energy. The reflection of this lower conversion is the reduction of the leaf area and a consequent reduction in the soybean growth and development. This shows that late sowing does not provide enough time for plants to grow normally until the beginning of the reproductive period, what, according to Amorim et al. (2011), leads to lower yields. Rodrigues et al. (2001), Rodrigues et al. (2008) and Stülp et al. (2009) also observed losses in late sowings, which reached 30$50 \%$ in grain yield (or up to $70 \%$ with off-season sowing), in relation to the recommended season.

\section{CONCLUSION}

The stomatal conductance, transpiration and photosynthesis rate in soybean reduce with the increase of water tension in the soil. A similar behavior was found for the intercellular $\mathrm{CO}_{2}$ concentration, which was not enough to increase the instantaneous carboxylation efficiency of the plants. This was negatively reflected in the shoot and root dry matter, with lower values in all the assessed cultivars. The leaf gas exchanges in the soybean plants were reduced with the increase of the water tension in the soil, with the most critical level being $25 \mathrm{kPa}$. The BRSMG 850 cultivar showed the best performance for the production of root dry matter.

\section{REFERENCES}

ALMEIDA, M. O.; FERREIRA, E. A.; SILVA, D. V.; SANTOS, J. B.; RODRIGUES, R. B.; SOUZA, B. P.; COSTA, S. S. D. Influência do tamanho do vaso e época de avaliação sobre o crescimento do picão preto em competição com milho e soja. Bioscience Journal, v. 30, n. 5, p. 1428-1437, 2014.

AMORIM, F. A.; HAMAWAKI, O. T.; SOUSA, L. B.; LANA, R. M. Q.; HAMAWAKI, C. D. L. Época de semeadura no potencial produtivo de soja em Uberlândia MG. Semina: Ciências Agrárias, v. 32, supl. 1, p. 17931802, 2011.

ASSAD, E.; SANO, E. Sistemas de informações geográficas: aplicação na agricultura. 2. ed. Brasília, DF: Embrapa, 1998.

BENJAMIN, J. G.; NIELSEN, D. C. Water deficit effects on root distribution of soybean, field pea and chickpea. Field Crops Research, v. 97, n. 2-3, p. 248-253, 2006.

BHATIA, V. S.; JUMRANI, K. A maximin-minimax approach for classifying soybean genotypes for drought tolerance based on yield potential and loss. Plant Breed, v. 135 , n. 6 , p. 691-700, 2016.

BLUM, A. Effective use of water (EUW) and not water-use efficiency (WUE) is the target of crop yield improvement under drought stress. Field Crops Research, v. 112, n. 2-3, p. 119-123, 2009.

BOSCO, M. R. O.; OLIVEIRA, A. B. de; HERNANDEZ, F. F. F.; LACERDA, C. F. Efeito do $\mathrm{NaCl}$ sobre o crescimento, fotossíntese e relações hídricas de plantas de berinjela. Revista Ceres, v. 56, n. 3, p. 296-302, 2009.

BRASIL. Ministério da Agricultura, Pecuária e Abastecimento. AgroStat: estatísticas do comércio exterior do agronegócio brasileiro. 2019. Disponível em: http:// indicadores.agricultura.gov.br/index.htm. Acesso em: 10 abr. 2019. 
CHAVARRIA, G.; DURIGON, M. R.; KLEIN, V. A.; KLEBER, H. Restrição fotossintética de plantas de soja sob variação de disponibilidade hídrica. Ciência Rural, v. 45, n. 8, p. 1387-1393, 2015.

EMPRESA BRASILEIRA DE PESQUISA AGROPECUÁRIA(Embrapa). Cultivares convencionais de soja: macrorregiões 3, 4 e 5. Londrina: Embrapa Soja, 2013.

EMPRESA BRASILEIRA DE PESQUISA AGROPECUÁRIA (Embrapa). Tecnologias de produção de soja: região central do Brasil 2012 e 2013. Londrina: Embrapa Soja, 2011.

FARIAS, J. R. B.; NEPOMUCENO, A. L.; NEUMAIER, N. Ecofisiologia da soja. Londrina: Embrapa Soja, 2007. (Circular técnica, 48).

FIOREZE, S. L.; PIVETTA, L. G.; FANO, A.; MACHADO, F. R.; GUIMARÃES, V. F. Comportamento de genótipos de soja submetidos a déficit hídrico intenso em casa de vegetação. Revista Ceres, v. 58, n. 3, p. 342-349, 2011.

FREITAS, C. A. S. D.; BEZERRA, F. M. L.; SILVA, A. R. A.; PEREIRA FILHO, J. V.; FEITOSA, D. R. C. Comportamento de cultivares de mamona em níveis de irrigação por gotejamento em Pentecoste, CE. Revista Brasileira de Engenharia Agrícola e Ambiental, v. 14, n. 10, p. 1059-1066, 2010.

GONÇALVES, E. R.; FERREIRA. V. M.; SILVA, J. V.; ENDRES, L.; BARBOSA, T. P.; DUARTE, V. G. Trocas gasosas e fluorescência da clorofila $a$ em variedades de cana-de-açúcar submetidas à deficiência hídrica. Revista Brasileira de Engenharia Agrícola e Ambiental, v. 14, n. 4, p. 378-386, 2010.

HONG-BO, S.; SHAO, H. B.; CHU, L. Y.; JALEEL, C. A.; ZHAO, C. X. Water deficit stress-induced anatomical changes in higher plants. Comptes Rendus Biologies, v. 331, n. 3, p. 215- 225, 2008.

HOPKINS, W. G.; HÜNER, P. A. N. Plant physiology. 4. ed. Hoboken: Wyley, 2009.

JUMRANI, K.; BHATIA, V. S. Impact of combined stress of high temperature and water deficit on growth and seed yield of soybean. Physiology and Molecular Biology of Plants, v. 24, n. 1, p. 37-50, 2017.

JUMRANI, K.; BHATIA, V. S.; PANDEY, G. P. Impact of elevated temperatures on specific leaf weight, stomatal density, photosynthesis and chlorophyll fluorescence in soybean. Photosynthesis Research, v. 131, n. 3, p. 333350, 2017.

KERBAUY, G. B. Fisiologia vegetal. 2. ed. Rio de Janeiro: Guanabara Koogan, 2008.

MACHADO JÚNIOR, C. S.; SILVA, C. R. da; SANCHES, M. C.; HAMAWAKI, O. T.; SOUSA, L. B. de.
Physiologic parameters of soybean of determinate and indeterminate growth habit subjected to levels of soil moisture. Pesquisa Agropecuária Brasileira, v. 52, n. 6, p. 419-425, 2017.

MALAVOLTA, E. Elementos de nutrição mineral de plantas. Piracicaba: Agronômica Ceres, 1980.

MANAVALAN, L. P.; GUTTKONDA, S. K.; NGUYEN, H. T. Physiological and molecular approaches to improve drought resistance in soybean. Plant Cell Physiology, v. 50, n. 7, p. 1260-1276, 2009.

MUALEM, Y. A new model for predicting the hydraulic conductivity of unsaturated porous media. Water Resources Research, v. 12, n. 3, p. 513-522, 1976.

R DEVELOPMENT CORE TEAM (RDCT). $R$ : a language and environment for statistical computing. Vienna: $\mathrm{R}$ Foundation for Statistical Computing, 2016.

RAHNAMA, A.; MUNNS, R.; POUSTINI, K.; WATT, M. A screening method to identify genetic variation in root growth responses to a salinity gradient. Journal of Experimental Botany, v. 62, n. 1, p. 69-77, 2011.

RIOS, G. F. A.; CARVAlHO, L. G.; SILVA, B. M.; REZENDE, F. C.; PEREIRA, G. M. Tensões de água no solo no cultivo de mamoneira. Pesquisa Agropecuária Tropical, v. 44, n. 3, p. 287-293, 2014.

RODRIGUES, O.; DIDONET, A. D.; LHAMBY, J. C. B.; BERTAGNOLLI, P. F.; LUZ, J. S. Resposta quantitativa do florescimento da soja à temperatura e ao fotoperíodo. Pesquisa Agropecuária Brasileira, v. 36, n. 3, p. 431-437, 2001.

RODRIGUES, O.; TEIXEIRA, M. C. C.; COSTENARO, E. R.; AVOZANI, A. Rendimento de grãos de soja em semeadura tardia. Passo Fundo: Embrapa Trigo, 2008. (Boletim de pesquisa e desenvolvimento, 66).

SANTOS, F. L.; ALEXANDRE, C.; COELHO, R. Relações solo-água-planta. In: SHAHIDIAN, S.; GUIMARÃES, R.; RODRIGUES, C. M. (ed.). Hidrologia agrícola. Évora: ICAAM, 2012. p. 153-203.

SILVA, A. J.; MAGALHÃES FILHO, J. R.; SALES, C. R. G.; PORES, R. C. M.; MACHADO, E, C. Source-sink relationships in two soybean cultivars with indeterminate growth under water deficit. Bragantia, v. 77, n. 1, p. 23 $35,2018$.

SILVA, F. G.; DUTRA, W. F.; DUTRA, A. F.; OLIVEIRA, I. M.; FILGUEIRAS, L. M.; MELO, A. S. Trocas gasosas e fluorescência da clorofila em plantas de berinjela sob lâminas de irrigação. Revista Brasileira de Engenharia Agrícola e Ambiental, v. 19, n. 10, p. 946-952, 2015.

STÜLP, M.; BRACCINI, A. de L. e; ALBRECHT, L. P.; ÁVILA, M. R.; SCAPIM, C. A.; SCHUSTER, I. 
Desempenho agronômico de três cultivares de soja em diferentes épocas de semeadura em duas safras. Ciência e Agrotecnologia, v. 33, n. 5, p. 1240-1248, 2009.

SYSTAT. SigmaPlot: version 12.3. San Jose: Systat, 2013.

TAIZ, L.; ZEIGER, E. Fisiologia vegetal. 6. ed. Porto Alegre: Artmed, 2017.
TARDIEU, F. Plant response to environmental conditions: assessing potential production, water demand and negative effects of water deficit. Frontiers in Physiology, v. 4, n. 1, p. 1-7, 2013.

VAN GENUCHTEN, V. M. T. A closed-form equation for predicting the hydraulic conductivity of unsaturated soil. Soil Science Society of America Journal, v. 44, n. 5, p. 892-898, 1980. 